\title{
Present AT THE RESURRECTION: ISLAMIC FINANCE AND ISLAMIC LAW
}

\author{
HAIDER ALA HAMOUDI*
}

INTRODUCTION 1107

I. PROFESSOR FRANK VOGEL AND THE NATURE OF

ISLAMIC LAW

II. DR. KILIAN BÄLZ AND BROADER LESSONS FOR

ISLAMIC LAW

III. PROFESSOR MAHMOUD EL GAMAL AND THE

NEGLECTED MUSLIM POOR

CONCLUSION

\section{INTRODUCTION}

Of all the recent attention given to the subject of Islamic law, perhaps the most unremarked upon, and yet also uncontested, observation is the extent to which the basic source material of the law, the vast compendia of norms and rules developed by medieval Muslim jurists - herein referred to as shari' $a^{1}$ - have been rendered

* Assistant Professor of Law, University of Pittsburgh School of Law. My gratitude and thanks extends in particular to Frank Vogel, Kilian Bälz, and Mahmoud El Gamal for their stimulating presentations, which provided the inspiration for this modest essay. As the essay is my own creation, I take full responsibility for all characterizations and errors present herein.

1. I am (intelligently and thoughtfully) criticized for often defining this vast and contradictory body of norms and rules developed by medieval jurists as shari'a, rather than fiqh. See, e.g., Patrick S. O'Donnell, Divine Law (Shari'ah) and Jurisprudence (Fiqh) in Islam, RATIO JURIS: LAW, POLITICS, PHILOSOPHY (A MEMBER OF THE JURISDYNAMICS NETWORK) (June 26, 2009, 10:58 AM), http://ratiojuris.blogspot.com/2009/06/divine-law-shariah-jurisprudence-fiqh.html.

It is true that the latter term is often used to describe the substantive rules derived by such jurists. See FRANK E. VOGEL \& SAMUEL L. HAYES III, ISLAMIC LAW AND FINANCE: RELIGION, RISK AND RETURN 23-24 (1998) (distinguishing between shari' $a$ as the immutable Divine Law and fiqh as human efforts to capture that law through scholarly interpretation). Yet at the same time my own realist predispositions lead me to the conclusion that if shari' $a$ is meant to refer to nothing beyond a perfect and immutable Divine Law separate and apart from any human 
obsolete by modernity. ${ }^{2}$ To be sure, this is not the case in all positive law in the modern Muslim nation state. Much to the chagrin of the portion of Muslim society enamored with modern conceptions of women's rights, both family law and the law of inheritance remain firmly based in shari'a discourse in most Muslim majority nations. ${ }^{3}$

effort to understand that law, then almost as a matter of epistemological necessity it means precisely nothing that can be known and is of no value to lawyers. Shari'a is not advanced even in American academic circles in such abstract terms, hence the insistence of Professor Feldman, for example, that the Iraqi constitution urges its legislature to "deploy the shari'a," a statement that is meaningless unless shari'a is in some way humanity's concretization of the Divine. See Noah Feldman, Response to Hamoudi, 2 MidDLE E. L. \& Gov'T J. 104, 105 (2010). This is to say nothing of the manner in which shari'a is used in modern Muslim discourse, where it absolutely includes references to some legal content. See, e.g., Clark Lombardi, State LaW as Islamic LaW in MOdern Egypt: The INCORPORATION OF THE SHARI'A INTO EGYPTIAN CONSTITUTIONAL LAW 180 (2006) (quoting Case no. 7/1993/Supreme Constitutional Court (Egypt)). Finally, and most appropriately for our purposes, the ubiquitous references to "shari" $a$ compliant ... financ[e]" confers upon shari'a a binding set of rules, not unknowable aspects of the Divine. Joseph DiVanna, Guest Column, FIN. TIMES (Dec. 13, 2010, 11:42 PM), http://www.ft.com/cms/s/0/fb0eab76-064b-11e0-976b00144feabdc0.html\#axzz1BVCMVkld. Accordingly, I find my own definition of shari' $a$, while admittedly contestable, nevertheless the most appropriate one to describe the corpus of the positive rules commonly referred to as "Islamic law," particularly in the area of Islamic finance.

2. See Bernard G. Weiss, The Spirit of Islamic LAW 188 (1998) (describing the adoption of civil, criminal, commercial, and other legal codes in Muslim countries, as a result of European colonialism, that modified or replaced traditional Islamic law); Lama Abu-Odeh, The Politics of (Mis)recognition: Islamic Law Pedagogy in American Academia, 52 AM. J. CoMP. L. 789, 791-92 (2004) (pointing to a scholar's flaw in applying traditional Islamic criminal law to contemporary situations when the courts of Islamic countries have adjudicated cases based on European criminal law for centuries); Haider Ala Hamoudi, The Death of Islamic Law, 38 GA. J. INT'L \& COMP. L. 293, 295-97 (2010) (indicating that Islamic states commonly adopt and apply laws transplanted from Western societies even though Islamist rhetoric insists that the law should be Divine rather than man-made).

3. WEISS, supra note 2, at 188; see Hamoudi, supra note 2, at 297 (contrasting Islamists' willingness to adopt man-made law in corporate law, contracts, and torts with Islamists' adamant obstruction of amendments or developments to family law, where they believe Divine law is necessary); see also Abu-Odeh, supra note 2, at 792 (referencing liberal use of Islamic law in family law matters). But see JUDITH E. TUCKER, WOMEN, FAMILY AND GENDER IN ISLAMIC LAW 65-83 (2008) (acknowledging changes to traditional Islamic family law as reformists attempt to reconcile a Qur'an-based view of marriage with modern marriage ideals); Baudouin Dupret, What is Islamic Law?: A Praxiological Answer and an Egyptian Case Study, 24 THEORY, CULTURE \& SOC'Y 79, 88-90 (2007) (acknowledging that 
Beyond this, the record is far more mixed, with some states adopting portions of shari'a in an otherwise thoroughly modern criminal code, ${ }^{4}$ or recognizing the continuation of the Islamic religious endowments known as the waqf. ${ }^{5}$

It is in the area of private law beyond family law and inheritance, however, where shari'a suffered the most dramatic decline. ${ }^{6}$ In the vast majority of Muslim nations, shari' $a$ rules of contract, tort, and most particularly partnership (including corporate law) were displaced by transplanted European law to such an extent that most Muslim lawyers in the Muslim world probably do not understand the medieval system in the slightest, much less be able to practice within any system that remotely resembled it. ${ }^{7}$

These core facts provide pivotal context to understand the relatively recent surge of interest in Islamic finance. ${ }^{8}$ While interest

modern judges applying family law are thoroughly bureaucratized administrative officials of a modern nation-state who apply a particular version of shari' $a$ that is tied to a set of procedural rules and professional responsibilities, leading them to approach their tasks entirely differently than a traditional Islamic judge from another era).

4. See generally RUdOLPH PETERS, CRIME AND PUNISHMENT IN ISLAMIC LAW: THEORY AND PRACTICE FROM THE SIXTEENTH TO THE TWENTY-FIRST CENTURY 155-73 (2005) (detailing the history of the movements and legislation that incorporated Islamic law into the criminal codes of Libya, Pakistan, Iran, Sudan, and northern Nigeria, or applied Islamic law alongside secular criminal laws).

5. See Haider Ala Hamoudi, Baghdad Booksellers, Basra Carpet Merchants, and the Law of God and Man: Legal Pluralism and the Contemporary Muslim Experience, 1 BERKELEY J. MIDDLE E. \& ISLAMIC L. 83, 107 (2008) (illustrating that the definitions of certain legal entities are rooted in shari'a, such as the "waqf," which can be translated as a Muslim charitable trust).

6. See Hamoudi, supra note 2, at 323-25 (asserting that Islamists neither challenged the promulgation and application of civil and common law nor insisted on the use of shari'a for private law matters, most specifically in the commercial law context).

7. See id. at 311 (calling attention to the fact that the legal education of the judiciary in Islamic states encompasses the civil and common law and not the shari'a). But see id. at 309-10 (suggesting that even though shari'a is becoming less relevant in private law, some Islamic concepts continue to survive the transplantation of European law-most specifically the shari'a concept of the waqf, or land trust, which continues to remain in the modern Civil Code).

8. See Kenneth Silber, The Rise of Islamic Finance, RESEARCH MAG. (Sept. 1, 2008), http://www.advisorone.com/article/rise-islamic-finance (noting the rise of interest in Islamic finance among Muslims and non-Muslims, particularly when lenders can employ certain methods to overcome shari'a's prohibition on interest); see also IBRAHIM WARDE, ISLAMIC FINANCE IN THE GLOBAL ECONOMY 1 (2000) 
in shari'a as it concerns private law (beyond family law) has generally declined within the broader Muslim polity to the point that the rules are not only obsolete, but also largely unknown, Islamic finance stands as a stark exception. It is an area of growing importance and relevance, and one that purports to be an application and modern resurrection of shari'a.

Admittedly, it is in large part a voluntary adherence to shari'a rather than a state-mandated one, as Islamic finance transactions in all but a handful of countries are not required by state law but rather ensured through a form of voluntary compliance, in a manner that will be addressed later in this essay. ${ }^{9}$ However, that solution hardly resolves the difficulty. Even positing that the practice is to be voluntary, how does one go about crafting rules and limitations to govern a deeply and fundamentally contemporary practice using source material that is medieval in its origin? This is not, after all, some sort of effort to revert to shari'a in all private law mattersthat would preclude any notion of legal personality, corporate limited liability, or general theory of contract. ${ }^{10}$ Islamic banks rely on every single one of these concepts of modernity and it seems obvious to say that they could not survive otherwise. The rise of Islamic finance is instead an effort to create sensible rules of application for modern financial institutions on the basis of particular medieval rules that

(noting that the first Islamic banks did not exist until the 1970s, but have since expanded operations to over seventy countries and have forty times the assets they did in the early 1980s).

9. See, e.g., Kristin Smith, The Kuwait Finance House and the Islamization of Public Life in Kuwait, in THE Politics OF Islamic FinanCe 168, 182 (Clement M. Henry \& Rodney Wilson eds., 2004) (illustrating how the Kuwait Finance House, the second largest bank in Kuwait, adheres to shari'a by maintaining a voluntary, rather than mandatory, system of complying with the Kuwait Central Bank, even though this voluntary scheme entails a number of institutional drawbacks); see also Edna Fernandes, Sharia Law UK: Mail on Sunday Gets Exclusive Access to a British Muslim Court, DAILY MaIL (July 4, 2009, 9:57 PM), http://www.daily mail.co.uk/news/article-1197478/Sharia-law-UK--How-Islam-dispensing-justiceside-British-courts.html\# (illustrating the rare changing tide in the United Kingdom to move from voluntary compliance with shari'a court rulings on financial disputes, to mandatory compliance by enforcing the shari'a court judgments through the state's civil courts).

10. E.g., Hamoudi, supra note 2, at 309 (pointing out the substantive legal problems with the Mecelle (Ottoman Civil Code) operating as a continental civil code, given its lack of "any concept of legal personhood" or notion of limited liability companies). 
hardly seem relevant to modernity. ${ }^{11}$ Ultimately, what the practice purports to do, its entire justificatory framework, lies in the resurrection of (selectively decided upon) rules of shari'a applied in a commercial and economic environment that bears no resemblance to that which existed at the time the rules were developed. ${ }^{12}$

To say that this challenge raises any number of thorny theoretical questions difficult to resolve is an understatement. The most obvious is the irony of the selectivity. For example, why may an Islamic bank enjoy legal personality in derogation of shari'a but may not take interest on a loan? This question, however, is a debate for another time and place, as it involves considerations well beyond those of Islamic finance alone. ${ }^{13}$

More to our purposes, precisely what is the Islamic methodology that is to be applied so as to glean, from disparate sets of juristic compendia spanning hundreds of years, a set of methodologically sound principles that might become the bedrock of a modern financial practice? More centrally, who will be entrusted to apply those principles to develop the relevant rules? Finally, will whatever hybrid creature that emerges from this primordial soup of rules, sacred texts, and purposes serve as an example for any attempt to resurrect other areas of Islamic law, either in terms of methodology or the location of institutionalized authority?

These questions are not easy to answer, and it is a testament to their difficulty that they are still being grappled with. Fortunately, the July 27, 2010 plenary session of the XVIIIth Congress of the International Academy of Comparative Law, the subject of this

11. See Haider Ala Hamoudi, The Muezzin's Call and the Dow Jones Bell: On the Necessity of Realism in the Study of Islamic Law, 56 AM. J. COMP. L. 423, 436 (2008) ("A modern legal code cannot truly be made from hundreds of contradictory juristic texts spanning over a thousand years, particularly when, as in matters of commerce and finance, the texts deal largely with material that is either irrelevant or deeply offensive to modern sensibilities ....").

12. See Haider Ala Hamoudi, Jurisprudential Schizophrenia: On Form and Function in Islamic Finance, 7 CHI. J. INT'L. L. 605, 610 (2007) (describing the shortcomings of the methodology of the modern jurisprudence in developing a uniform set of rules).

13. I have discussed elsewhere the rather odd selectivity of legal areas in which Islamist groups appear to engage. Some obvious departures from shari'a are ignored (such as the universal modern prohibition against slavery), while others are deemed indispensable (such as money interest on a loan). 
essay, provided an ideal opportunity to explore such matters in greater depth and included a panel of speakers that was as diverse as it was distinguished. ${ }^{14}$ While each speaker spoke to his own area of interest and expertise, and each focused on a disparate aspect of Islamic finance, what united the presentations can be brought back to what might be called a core aspect of modern Islamic finance-what is its relationship to the shari'a, and who gets to decide core questions of Islamicity? This essay shall explore each presentation in more detail to highlight the ways in which these ideas manifest themselves in different aspects of Islamic finance and its alternatives.

\section{PROFESSOR FRANK VOGEL AND THE NATURE OF ISLAMIC LAW}

Professor Vogel's initial contribution framed the question presented in this essay with far more historical nuance and with reference to the substance of the shari'a itself. Professor Vogel's primary task was to narrate the manner in which Islamic law developed positive rules and the manner in which those rules might be used to construct, or in this case to resurrect, a framework of regulation. ${ }^{15}$

As would be appropriate in any exposition on law in a foreign context, Professor Vogel centers the conversation squarely on the matter of authority. In other words, and to expand on his ideas in a manner relevant to this essay, Muslims consider that under core theological principles, Islam's holiest texts arise from God and are provided to humanity in the form of Revelation to the Prophet Muhammad. ${ }^{16}$ Without more, under this reduced paradigm, the only source material of the law is the Revealed Book of God, the Qur'an, and the example of the Prophet himself in the form of his deeds,

14. The XVIIIth International Congress of the International Academy of Comparative Law, INT'L ACAD. COMP. L., http://www.iuscomparatum.org/141 _p_4109/washington-congress-2010.html (last visited July 1, 2011).

15. Frank Vogel, Former Dir., Islamic Legal Studies Program, Harvard Law School, Remarks at the Islamic Finance Plenary Session of the XVIIIth Proceedings of the International Academy of Comparative Law (July 27, 2010) [hereinafter Vogel Presentation] (transcript on file with American University International Law Review).

16. M. Cherif Bassiouni \& Gamal M. Badr, The Shari'ah: Sources, Interpretation and Rule-Making, 1 U.C.L.A. J. ISLAMIC \& NEAR E. L. 135, 147-48 (2002) (describing core conception of revelation in the Islamic tradition). 
words, and utterances, known as the Sunna. ${ }^{17}$ Following this paradigm, without elaboration, any number of Muslims reflexively and seemingly un-contemplatively "hurl"18 pieces of the Sunna at one another to demonstrate the obvious truth of some principle or other, in a manner entirely disassociated from any political context or any ethical framework.

As a historical matter, and among Muslims who take their doctrinal traditions seriously, the matter is not such an "exegetical free-for-all," 19 and the question Vogel chooses to focus on is not what the source material of the law should be, nor even the methodology used to interpret the source material (though that is of some importance), but rather who will be entrusted with its interpretation? In short, who may undertake the effort, referred to in Arabic as ijtihad, to derive the rules from the source material? ${ }^{20}$

Professor Vogel then initiated the analysis and began with Schacht's well-known statement that Islamic law represents an "extreme case of a 'jurists" law." ${ }^{21}$ Stated more fully, as the shari'a developed, its substance was not decided by a political authority, such as a caliph, nor by state officials, such as a judiciary, nor by any other sort of state sanctioned body, ${ }^{22}$ but rather by particular schools

17. See Joseph Schacht, The ORIGINS OF MUHAMmadAN JuRISPRUdENCE 2 (1950) (defining the Sunna as the behavior and traditions of the Prophet Muhammad and stating that the two recognized sources of Islamic law are the Qur'an and the Sunna); Russell Powell, Zakat: Drawing Insights for Legal Theory and Economic Policy from Islamic Jurisprudence, 7 PITT. TAX REV. 43, 50-51 (2007) (describing the various canonical texts of Sunna in the Sunni tradition that are used to interpret the Qur'an and that supply a large body of legal precedent in Islamic law).

18. See Khaled Abou El Fadl, The Great Theft: Wrestling Islam From THE EXTREMISTS 90 (2005) (using Ghazali's metaphor, made famous in the English language by El Fadl, to refer to the attempts of particular modern fundamentalists, untrained in legal theory and analysis, to apply the law by "hurling traditions at their opponents to score cheap points").

19. ANDREW F. MARCh, ISLAM and Liberal Citizenship: The SEARCH FOR AN OVERLAPPING CONSENSUS 68 (2009) (using the phrase to describe the process of examining religious rules without considering a religion's doctrinal underpinnings).

20. See Bassiouni \& Badr, supra note 16, at 153 (describing ijtihad as developing a legal opinion based on the sources of law).

21. JOSEPH SCHACHT, AN INTRODUCTION TO ISLAMIC LAW 209 (1982).

22. See LOMBARDI, supra note 1, at 49-54 (presenting the Islamic argument for a revival of the theory that a political authority can promulgate rules for the greater 
of thought entirely divorced from state control. Ultimately, four such schools emerged in the Sunni tradition, described accurately as guilds by the late Professor George Makdisi because of their institutional similarity to that Western medieval institution. ${ }^{23}$ Individual jurists within each guild developed vast compendia of rules derived within their respective schools, and it is the sum corpus of these contradictory, varying, and immense compendia that form the substance of the rules from which Islamic law is derived.

The problem is that, with the advent of the colonial era, the juristic schools lessened in importance and ultimately disappeared in large parts of the Muslim world. ${ }^{24}$ To compound the difficulty, with the rise of the nation-state came not only transplanted law, but also transplanted political institutions and bureaucratic and administrative procedures. This process began as late as the end of the eighteenth century, ${ }^{25}$ and was therefore long complete by the creation of the first Islamic banks near the end of the twentieth century.

So then, what is an emerging "Islamic" financial practice to do in order to make determinations respecting the shari'a compliance of its activities? There appears to be at least three options. First, one could adopt the ideas of one particular school of thought. However, such an approach is fundamentally limiting in terms of acceptable rules that may be derived, and it appears antiquated because the schools, as vibrant rulemaking institutions, no longer exist. Second,

public good, thus enabling the state to enact positive law while shari' $a$ retains a function within the state). But see Hamoudi, supra note 2, at 328-32 (questioning whether states can sensibly and with internal consistency retain a role for shari'a in the Islamic state, while also enacting positive law that may contradict shari'a, such as legislation that promotes women's rights).

23. See SHERMAN A. JACKSON, Islamic LAW AND THE STATE: THE CONSTITUTIONAL JURISPRUDENCE OF SHIHĀB AL-DĪN AL-QARĀFī 103-04 (1996) (explaining and critiquing Professor Makdisi's claim that the Sunni's madhhabs, or schools of legal thought, satisfied the criteria for guilds because they were professional, took up a specific economic sector, strictly regulated who could receive licenses to teach and give legal opinions, were independent from government, used a hierarchical structure, and were led by a headman).

24. See EL FADL, supra note 18, at 35-37 (detailing the systematic nationalization, secularization, and limits to legal education imposed upon shari'a schools that led to the schools closing or producing only religious ministers rather than jurists).

25. See id. at 26 (explaining that the process began with the "age of colonialism"). 
some fusion of the four schools could be undertaken. But, would such an approach even be defensible, given that each school, at least in theory, developed rules according to a distinct set of methodological doctrinal principles, not susceptible of being stitched together artificially after a period of centuries to address modern concerns? Third, perhaps an entirely fresh approach is warranted. The original sacred text could be reinterpreted in a way that derogates from earlier juristic rules-a process Abduh referred to as the reopening of the gates of ijtihad? ${ }^{26}$

Professor Vogel has indicated that the approach of Islamic finance has generally chosen the second of the three options above. That is, finance rules are selected from among all four schools on largely functional principles, favoring rules that operate best under modern circumstances. ${ }^{27}$ Elsewhere Professor Vogel indicated that this functional drive is balanced against a need to not de-contextualize individual rules or "patch" them together in a manner that deprives the Islamic system of what he refers to as its "internal logic." ${ }^{28}$ The qualification is necessary, for it would not be difficult to create from the disparate fabric of over a millennium of juristic rules a set of principles that satisfy any interpreter, whether he is Vladimir Lenin, Milton Friedman, or Osama Bin Laden. The solution lies in the putative balance of logic on the one side and utilitarian selection on the other.

However, the idea of adopting rules from four schools on the basis of the methods described above does leave open the very question of authority with which his presentation began. That is to say, in the absence of juristic schools, one might well ask who will be entrusted with this task of determining what is legitimate functional choice and what is irresponsible patching together of de-contextualized rules. This would be a problem regardless of which rules were adopted, but

26. See Haider Ala Hamoudi, Muhammad's Social Justice or Muslim Cant: Langdellianism and the Rise of Islamic Finance, 40 CORNELL INT'L L.J. 89, 127-28 n.225 (2007) (illustrating the broad scope of reforms that may be needed in order to resurrect the development of legal rules, such as the "expansive use of reason" to promote Islamic "solutions to the problems of modern society").

27. Vogel Presentation, supra note 15.

28. VOGEL \& HAYES, supra note 1, at 37-38 (cautioning against constructing legal rules that are replicas of Western legal rules by picking and choosing preferred rules in a de-contextualized fashion). 
when the methodology is to synthesize disparate sets of rules into a whole that never previously existed, the problem becomes particularly acute.

The point, to be clear, is not that such determinations will not be subject to criticism by academics who will claim that they are less reflections on sacred text than responses to external economic and ideological stimuli operating in the relevant social space, though that is an assertion I have made in other contexts. ${ }^{29}$ Rather, the point is that perceptions of legitimacy within the community will certainly depend on the extent to which those doing the interpreting, and the synthesizing of rules from among the four schools, are deemed to be authentic.

This was not a question that Professor Vogel sought to answer, nor should it have been. His remarks were not designed to provide solutions, but only to raise the proper questions in Islamic finance, a matter he undertook with considerable success.

\section{DR. KILIAN BÄLZ AND BROADER LESSONS FOR ISLAMIC LAW}

Dr. Bälz picked up with the very question of authority that Professor Vogel left open. ${ }^{30}$ To Dr. Bälz, this question of authority in Islamic finance, and the matter of who determines Islamicity, is the central question with which to grapple.

In this context, the voluntary nature of Islamic finance is of fundamental importance because it removes the state, the judiciary, and the jurists as the agents of legal change or as the authority responsible for interpreting shari' $a .^{31}$ The practice is not based on state law, as the contracts pursuant to which Islamic finance is

29. See Hamoudi, supra note 11, at 437-38 (criticizing "internal logic" in shari'a as merely a confirmation of a particular preexisting set of ideological and normative commitments).

30. Kilian Bälz, Partner, Amereller Legal Consultants, Remarks at the Islamic Finance Plenary Session of the XVIIIth Proceedings of the International Academy of Comparative Law (July 27, 2010) [hereinafter Bälz Presentation] (transcript on file with American University International Law Review).

31. See generally ABdullahi Ahmed An NA'IM, Islam AND the SECular STATE: NeGOTIATING THE FUTURE OF SHARI'A 293 (2008) (positing that enforcing mandatory compliance of shari'a is not within the duties of the state because shari' $a$ is inherently diverse where state authority is uniform). 
organized are governed by foreign law (often New York or English law), marginalizing the role of state officers to make many determinations about the content of Islamic law. This is doubly so because of the frequency of arbitration clauses rendering the judge's role an exceedingly marginal one. ${ }^{32}$

There is a reason that this has been undertaken, and state influence has been minimized. The driving concern among practitioners is not that state courts and state officials will ignore shari'a, but that shari' $a$ will be given undue attention. There is a clear fear that if a particular financial structure is carefully established by practitioners and agents of Islamic finance, and a court is given an opportunity, it may gleefully dispute the Islamicity of the structure and declare it invalid under core Islamic principles. This problem is particularly acute in the Islamic finance context given the approach the practice has undertaken, as described effectively by Professor Vogel, to develop its rules of practice. If, after all, what we have in Islamic finance is a rather artificial synthesis of disparate rules of four medieval Islamic schools patched together by some sort of internal logic, it would not be difficult for a judge to reach an entirely different conclusion on how the synthesis should have been undertaken, and to disallow a structure that violated that judge's own vision.

The prospect that this may occur, and the dangers it creates respecting enforceability, were described by Dr. Bälz appropriately as "shari'a risk," meaning that the invocation of shari'a is the perceived bar to enforceability, not the mechanism by which it will be enforced..$^{33}$ The danger is considerable enough that not only is New York law chosen (so as to ensure that the contract is enforced according to its terms), but also there is an increasing proliferation of what Dr. Bälz referred to as "Waiver of Shari'a Defense" clauses, which prevent the parties from being able to assert in court that the transaction in question is not compliant with shari'a as a defense to enforceability. ${ }^{34}$ This concept led Dr. Bälz to characterize Islamic finance not so much as a legal practice, but as one derived from ethics.

32. See Bälz Presentation, supra note 30.

33. Id.

34. $I d$. 
While Dr. Bälz is clearly on to something, this terminology can be criticized; ethics are generally understood as standard-driven maxims of loose applicability whose purposes are not thwarted by formal evasion. ${ }^{35}$ Islamic finance is replete with formal artifices to avoid transactions that would otherwise be prohibited and is designed for the specific purpose of rule avoidance, which is hardly characteristic of most ethical frameworks. ${ }^{36}$ The simplest and most controversial example is the tawarruq, a form of synthetic sale and markup where the bank buys a particular item from a straw man and sells it at a markup reflecting prevailing interest rates to the borrower. The balance is to be paid in installments over the course of a particular period of time, but well before this, in fact immediately after its initial purchase, the item is resold for cash to the original seller for its original price, with no time elapsing between the three sales (straw man to bank, bank to borrower, and borrower back to straw man). The item never leaves its warehouse, and the borrower receives a sum certain in cash with an obligation to pay it back to the bank at a higher rate that corresponds precisely to market rates. ${ }^{37}$ One could criticize such an artifice as inauthentic or defend it as in keeping with formal rules, but it is hard to see precisely how one could argue that the practice has very much to do with ethics. Still, Dr. Bälz's distinction between reliance on state law and private ordering is an apt one.

As a result of this privatization of shari'a, the main set of institutions responsible for determining shari'a compliance, or the highly disembodied and dissolute authority to apply rules to govern financial transactions, are what is known as "shari' whose review and approval must be obtained for any transaction. ${ }^{38}$ These are generally selected and approved by the practitioners

35. See Immanuel Kant, The MetaphysicAl Elements of Ethics 20 (Great Books Found. 1949) (1780) (explaining that ethics produces universal principles to which every person should strive, and there should be no exceptions to making those principles one's own).

36. See Hamoudi, supra note 26, at 118 (claiming that Islamic financial institutions often depend on the complicated nature of the commercial structures in order to confuse Muslim consumers).

37. Id. at 119-20.

38. See Hamoudi, supra note 5, at 101 (explaining the significant role and binding nature of the shari'a review board, as a non-state actor, in judging compliance with shari'a). 
designing the transaction. Equally important, however, and the true source of innovation, are the law firms, accounting firms, and investment banking institutions which create vehicles that conform to the requirements of the shari'a review boards and yet still meet consumer demands. ${ }^{39}$

Equally relevant is the fact that this model of private ordering and reliance on non-state mechanisms and institutions could prove relevant in areas of private law, ranging from the Islamic law of contract (Dr. Bälz's example) to the law of the family (my example), where Muslims - particularly in liberal states-refer matters of dispute to the local imam and address any disputes arising internally without state assistance or intervention.

In other words, Dr. Bälz does offer us a solution to the conundrum of how to adopt medieval rules into a modern practice, largely by leapfrogging over matters of responsible methodology and arriving at the more fundamental question of locating a legitimate authority to undertake it. To Dr. Bälz, the truly fascinating and innovative aspect of Islamic finance is that the authority in question is in fact private and more intimately tied to the modalities of operation of international finance than any court. ${ }^{40}$

\section{PROFESSOR MAHMOUD EL GAMAL AND THE NEGLECTED MUSLIM POOR}

The one aspect left unaddressed by Dr. Bälz is the legitimacy of that disembodied and decentralized authority among the broader Muslim polity. Far from the self-financed guilds of jurists of the medieval era, these private actors are hired by the firms looking for transaction approval, often on a transaction by transaction basis, are paid by those firms, may be discharged by those firms, and generally are under confidentiality obligations not to disclose the details of the transactions on which they have worked..$^{41}$ The lack of impartiality is obvious-quite clearly any shari'a review board member who developed a reputation for being obstinate or difficult would have a hard time finding work, while those who were more willing to be flexible and accommodating to the demands of the law firms and

39. But see Hamoudi, supra note 26, at 118.

40. Bälz Presentation, supra note 30.

41. Id. 
banks responsible for hiring them would be financially rewarded for the same. This is hardly the basis upon which a broadly legitimate and independent interpretive authority can be established, a point Dr. Bälz did not contest.

Professor El Gamal spent substantial time offering a critique along these lines. Professor El Gamal found no legitimacy in the institutions that comprised Islamic finance, and correspondingly, no authenticity to their means of deriving medieval rules. ${ }^{42}$ Professor El Gamal has moreover offered elsewhere a thoughtful alternative set of ideas to what he views as a more responsible way to understand shari' $a$ as developed by the medieval jurists, and how to use the principles underlying their rules to create a more sensible system. ${ }^{43}$ However, the focus of his presentation, in keeping with the themes of the other two participants, focused on the relationship between the methodology and the authority, rather than solely on matters of hermeneutics. ${ }^{44}$

Professor El Gamal maintains that the practice of Islamic finance, and thus implicitly the authority underlying it, about which Dr. Bälz generally spoke in positive terms, has failed the broader Muslim community. There is always this danger whenever regulation of lawmaking institutions is left in private hands. While none could doubt that state officials have their own interests to protect, the interests of private actors, who stand to profit considerably if some interpretations are developed to the derogation of others, are comparatively larger. The risk that the rules will then be developed in a way that serves the interests of the financial classes alone thereby becomes quite a severe one..$^{45}$

42. Mahmoud El Gamal, Professor of Economics, Rice Univ., at the Islamic Finance Plenary Session of the XVIIIth Proceedings of the International Academy of Comparative Law (July 27, 2010) [hereinafter El Gamal Presentation] (transcript on file with American University International Law Review).

43. See generally Mahmoud A. El-Gamal, An Economic Explication of the Prohibition of Ribā in Classical Islamic Jurisprudence 1-18 (May 2, 2001), http://www.ruf.rice.edu/ elgamal/files/riba.pdf (arguing that medieval jurist 'Ibn Rushd's rationale for prohibiting Ribā contains elements of modern economic theory, specifically relating to the maximization of economic efficiency).

44. El Gamal Presentation, supra note 42.

45. See Kilian Bälz, Visiting Scholar, Islamic Legal Studies Program, Harv. L. School, Sharia Risk? How Islamic Finance Has Transformed Islamic Contract Law 25 (May 1, 2008) (transcript available at http://www.law.harvard.edu/programs/ ilsp/publications/balz.pdf) (pointing out that market forces and private actors 
Thus, Professor El Gamal insists, the practice has developed in a manner not designed to protect or serve the Muslim public, but to maximize profit. ${ }^{46}$ The transaction must be structured in a manner that will appeal to Muslim consumers, but it could never be fairly said that shari'a review boards do very much to serve the broader Muslim polity or (Professor El Gamal's focus) the Muslim poor. Given that the boards and the innovators of Islamic finance under Dr. Bälz's paradigm are responsible for articulating a modern Islamic legal practice, the question raised by Professor El Gamal's presentation is whether their disconnection from that polity and their intimate familiarity with international finance is not as much a hindrance as a benefit to ensure both authenticity and the continued viability of Islamic financial practice.

Professor El Gamal's solution accepts the reality of the private ordering that Dr. Bälz effectively lays out, for it seems inconceivable that Islamic finance is likely to be reorganized to serve primarily the Muslim poor. ${ }^{47}$ Rather, Professor El Gamal seeks to use private ordering as a means to serve the Muslim poor through a form of micro-financing that neither contravenes contemporary notions of a prohibition on interest, nor adopts for-profit financing mechanisms, relying instead on Islam-compliant commutative structures and mutual cooperatives that support economic development and are based on organic models in the region. ${ }^{48}$

The thrust of the claim is that it works. Perhaps anticipating the critique that social justice financing initiatives are noble in their intentions but are hardly the basis for a sustained practice, Professor El Gamal spent much of his presentation offering a wealth of careful empirical information to show that the cooperative was successful, in

determine how Islamic financial law develops even when the state dictates law reform generally or implements policies aimed at creating a purely Islamic state).

46. See id. at 24-26 (arguing that international commercial law heavily influences Islamic finance law).

47. See Imtiaz B. Ali, WAQF: A Sustainable Development Institution FOR MUSLIM COMMUNITIES 15 (2009), available at http://www.takaafultt.org/ images/WAQF_Book.pdf (explaining that the more recently proposed waqf microfinancing system would likely only succeed in non-Muslim states with a minority population of Muslim poor because in states where Muslims are minorities there is a stronger need to develop their Muslim communities and protect and promote Islam).

48. El Gamal Presentation, supra note 42. 
fact more successful than comparable micro-financing institutions. ${ }^{49}$ This achievement possibly is due to its compliance with common understandings of shari' $a$ as manifested in the modern world as well as its dedication to serving a Muslim underclass largely ignored by contemporary Islamic finance.

\section{CONCLUSION}

Despite nearly half a century of progress and an explosion of interest, Islamic finance appears to struggle with many of the problems common to most features of reinvigorated shari' $a .^{50}$ These problems center around one essential and indeed existential difficulty. To be relevant and applicable in the modern world, shari'a requires reinvigoration of fresh ideas to decide which of the historic rules will be used to maintain what Professor Vogel would call Islamic "internal logic." Yet for change to occur in any legal tradition, much less a religiously based one, it requires a legitimate agent. Many of the disputes and disagreements in Islamic finance are mere manifestations of this problem. Dr. Bälz located legitimacy and authenticity in the private actors that control Islamic finance, where Professor El Gamal dismissed them as self-interested, engaged in acts of "shari' $a$-arbitrage" and therefore not the basis of a long-term sustainable practice. With shari'a, the problem is not necessarily a lack of fresh ideas, as evidenced by the speakers' presentations. Indeed, the same might be said of other thinkers in other aspects of shari'a-Khaled Abou El Fadl respecting democracy, ${ }^{51}$ Abdullahi An Naim concerning secularism, ${ }^{52}$ and Andrew March concerning liberalism..$^{53}$ The problem in Islamic finance tends to be the lack of an authority that can articulate and apply these fresh ideas to promote

49. $I d$.

50. See generally Hamoudi, supra note 26, at 116-124 (explaining the failures of Islamic finance and discussing the dynamic complexities between traditional Islamic shari'a principles and modern international commercial law).

51. See generally Khaled ABOU El FADL, Islam AND THE Challenge of DEMOCRACY 65-66 (Joshua Cohen \& Deborah Chasman eds., 2004) (encouraging a "free society in which all Muslims can debate what constitutes Shari'ah").

52. See generally AN NA'IM, supra note 31, at 4, 95 (arguing that Muslims will be able to voluntarily adhere to shari' $a$ and not be forced to comply with a stateendorsed artificially narrow conception of shari' $a$ when they are in a secular state).

53. See generally MARCH, supra note 19, at 64, 71 (asserting that the framework of a liberal democracy is not necessarily opposed to Islamic principles and arguing a liberal justification for these principles). 
a broader communal acceptance..$^{54}$ That Islamic finance rules are intensely criticized as formalistic and illegitimate, by respected figures like Professor El Gamal, ${ }^{55}$ despite the fact that finance rules are among the most successful efforts at shari'a reinvigoration, illustrates how deep the problem runs.

54. See EL FADL, supra note 51, at 35-37 (showing why there may be a lack of modern Islamic legal scholars to promulgate new ideas).

55. See also Hamoudi, supra note 12, at 610 (expressing similar misgivings to Professor El Gamal on whether the modern application of shari'a accomplishes either the theoretical or practical goals that would help make traditional shari'a relevant in modern contexts). 